\title{
REMUNERATION AND CREATION OF VALUE FOR STAKEHOLDERS: ECONOMIC VALUE ADDED AS A MANAGEMENT TOOL
}

\author{
Leonardo Fernando Cruz Basso* \\ Department of Economics, Mackenzie Presbyterian University
}

(Received 6 november 2001, accepted 15 march 2002)

\begin{abstract}
Economic Value Added (EVA) has become a widely accepted tool in developed economies to measure the value created by a frm. The first advantage of using EVA with respect to other traditional measures is that it considers a cost for equity capital (Stewart, 1991). The second advantage of using such a measure is that it differs from accounting measures by suggesting adjustments that transform all measured quantities from the accrual basis into the cash basis. The purpose of this paper is to demonstrate that variable remuneration represents a higher economic value added for the firm when it is linked to productivity increases.
\end{abstract}

\section{Resumen}

El valor económico agregado (EVA por sus siglas en inglés) se ha convertido en una herramienta ampliamente aceptada en economías desarrolladas para medir el valor creado por una empresa. La primera ventaja al utilizar EVA con respecto a otras medidas tradicionales es que considera un costo por títulos de capital (Stewart, 1991). La segunda ventaja al utilizar dicha medida es que difiere de medidas contables sugiriendo los ajustes que transforman todas las cantidades medidas en la base acumulada a la base del efectivo. El propósito de este trabajo es demostrar que la remuneración variable representa un valor agregado económico más alto para la empresa cuando se asocia a incrementos en la productividad.

JEL classification: D21, M2

Keywords: Firm behavior, Business economics, Productivity

* Department of Economics, Mackenzie Presbyterian University, Rua da Consolação, 896, 6o andar, São Paulo, Brasil, Cep: 01302-907, Telephone: (55)(11)32368597, E-mail: leonardobasso@mackenzie.com.br

The author is very grateful to the anonymous referees for their comments 


\section{Introduction}

In Brazil, variable remuneration has been discussed extensively, but the effective deployment and implementation of these programs has not progressed far when associated with value creation. This represents evidence for stock option programs, where options are exercised when the share price increases. This may be extremely advantageous for stockholders (firm owners and executives having stock options) but has no relation whatsoever with the increase of economic value added, neither do these programs privilege the majority of stakeholders (firm employees), which occurs in the case of gainsharing programs that we will discuss further on. The purpose of this work is to demonstrate that variable remuneration can produce higher economic value added for stakeholders when linked to productivity increases. The connection between EVA and increases in productivity expands the potential of this management indicator to cover value creation since productivity increases as branded by gainsharing programs lead to an increase in value creation. As fixed remuneration is not linked to increases in productivity this type of remuneration is harmful to the creation of value.

We intend to concentrate, exclusively, on incentive programs for the firm as a whole, since in our opinion plans segmented by business units act against the sharing of competencies (Prahalad, 1999). The main characteristic of these plans is that they are structured to enable employees to share in the cost reduction produced by the joint efforts of the entire staff. Since cost reduction is a core issue in competitive strategies where prices can vary to a large extent, these programs collaborate to improve firms' competitive advantage and are related to the creation of value for the firm, as we will seek to demonstrate. We have emphasized the word "stakeholders" since we intend to demonstrate that an increase in economic value added derived from a productivity increase can benefit stockholders, executives, and employees from medium and low hierarchical levels, provided the latter are awarded for a greater creation of value than the executives.

This paper is organized in three sections. In the first section, we will examine three forms of gainsharing, stressing their association with productivity. In the second section, we will be analyzing Brazilian legislation related to profit and net income sharing and the respective emphasis on productivity. Finally, in the third section, we will explore the potential of value creation utilizing the EVA approach and its association with productivity. The characteristic shared by the three sections is the relation with productivity, which leads to the premise that profit sharing should be associated with productivity gains, as in this manner we are privileging value creation.

\section{Gainsharing programs}

\subsection{Scanlon plan}

This plan was developed by Joseph Scanlon from the American Iron Metallurgy Trade Union (Bergmann, Scarpello and Hills, 1998). In this plan, a formula determines the participation of employees in the sum of reduced costs. Table 1 
presents the Scanlon's methodology. Firstly, the firm determines the proportion of the payroll cost in relation to the gross production value. For example, suppose that firm utilized 500,000 Brazilian reais $(\mathrm{R} \$$ ) of the payroll to produce $\mathrm{R} \$ 2$ million in sales. The payroll percentage for the sales value was $25 \%$. Secondly, the firm determines the total savings resulting from the increase in efficiency. Thus if the payroll drops from $R \$ 500,000$ to $R \$ 400,000$ over sales of $R \$ 2$ million, the savings amount to $R \$ 100,000$. The applicability of this example to Brazil can be questioned as we are contemplating a salary reduction. In the case of Brazil we should perform an adaptation by increasing sales in relation to a fixed payroll. Thirdly, the firm allocates the participation of its

The Scanlon Plan is based on an elaborate system of suggestions and recommendations from employees about how to increase efficiency. Firms generally form a departmental committee with one or more workers and managers to study cost reduction suggestions and to focus efforts to make them more effective. Suggestions are implemented, postponed or rejected and the motives and justifications for their treatment are divulged to the interested parties. With the Scanlon Plan administrative goals and the personal goals of employees must be convergent. In environments undergoing constant change and with a culturally diverse workforce, pressure on employees to maintain convergent goals is significant. Furthermore, both parties must assume a strong commitment to increase sales that are ultimately responsible for determining the increase of the sales/payroll ratio. The formula developed by profit distribution programs should apportion productivity increases in a convincing manner. The plan is equivalent to a profit distr

The maintenance of the integrity of the Scanlon Plan is sustained by the determination of an accurate payroll standard with a proportion of the sales value and reliable commitment between capital and labor since otherwise employees could think of it as a management tool designed to manipulate them. Few organizations adopt the Scanlon Plan. One of the reasons is related to the fact that plans require a considerable commitment from management to establish the standards and to maintain them in operation. If these conditions are not present, an organization is probably not prepared to implement the Scanlon Plan. Our objective in this work is to emphasize the relevance of these plans due to the fact that they prioritize the creation of value for the firm, i.e., the economic income expressed in the EVA sum. 
Table 1. Theoretical Example of a Scanlon Plan Cost-Saving Based Bonus.

\begin{tabular}{|c|c|}
\hline Gross Output Value & $\mathrm{R} \$ 2,000,000$ \\
\hline Standard Labor Cost & $\mathrm{R} \$ 500,000$ \\
\hline Labor in Gross Output Value & $25 \%$ of $(\mathrm{R} \$ 500,000 / \mathrm{R} \$ 2,000,000)$ \\
\hline Current Labor Cost & $\mathrm{R} \$ 400,000$ \\
\hline Effective Savings & $\mathrm{R} \$ 500,000-\mathrm{R} \$ 400,000=\mathrm{R} \$ 100,000$ \\
\hline Deficit Reserve & $(25 \%$ of $\mathrm{R} \$ 100,000)=\mathrm{R} \$ 25,000$ \\
\hline Management Share & $(25 \%$ of $\mathrm{R} \$ 75,000)=18,750$ \\
\hline Employees' Share* & $(75 \%$ of $\mathrm{R} \$ 75,000)=\mathrm{R} \$ 56,250$ \\
\hline
\end{tabular}

* This is allocated to each worker based on that worker's yield as a percentage of the total payroll of the period.

Source: Bergmann, Scarpello, and Hills, Compensation Decision Making, Third Edition, The Dryden Press, New York, 1998, p. 432.

\subsection{Rucker plan}

The Rucker Plan is similar to the Scanlon Plan although with a difference in calculating the labor ratio, which is no longer expressed as the ratio between the payroll and sales. The main reason is the proportion of the payroll over value added, which as we will see in the development of the EVA formula, is classified as the difference between the gross output value and intermediate consumption. (Bergmann, Scarpello and Hills, 1998). This ratio is called the economic productivity index. It is determined by dividing the value added by labor (the output sales value less the costs of materials, suppliers and others) by the cost of labor (payroll of the period). An illustartion is presented in Table 2. Of the 100,000 reais saved and attributed to labor, one third is allocated to a reserve fund, while the remaining two thirds are distributed on a monthly basis. At the end of the fiscal period, part of the reserve not utilized to cover surplus labor costs derived from unpredictable events is distributed amongst the staff.

Table 2. Theoretical Example of a Rucker Plan Calculation.

\begin{tabular}{|c|c|}
\hline \multicolumn{2}{|c|}{ Historical Data } \\
\hline Gross Output Value & $\mathrm{R} \$ 2,000,000$ \\
\hline Cost of raw material & $\mathrm{R} \$ 1,000,000$ \\
\hline Value added $(V A)$ & $\mathrm{R} \$ 1,000,000$ \\
\hline Standard cost of labor R $\$ 2,000,000$ & $\mathrm{R} \$ 500,000$ \\
\hline Labor \% in Value Added $(L C V A)$ & $\mathrm{R} \$ 500,000 / \mathrm{R} \$ 1,000,000=0.5$ \\
\hline Economic Productivity Indcx $(E P I)$ & $1 / L C V A=2.0$ \\
\hline \multicolumn{2}{|c|}{ Bonus Period Data } \\
\hline Gross Output Value & $\mathrm{R} \$ 2.000,000$ \\
\hline Cost of Raw Matcrial & $\mathrm{R} \$ 1.000,000$ \\
\hline Value Added $(V A)$ & $\mathrm{R} \$ 1,000,000$ \\
\hline Cost of Labor $(C O L)$ & $\mathrm{R} \$ 400,000$ \\
\hline
\end{tabular}


Current Production Value = Gross Output Value

$$
\begin{aligned}
& \text { - (Cost of raw material + Cost of labor) } \\
& =\mathrm{R} \$ 2,000,000-(\mathrm{R} \$ 1,000,000+\mathrm{R} \$ 400,000)
\end{aligned}
$$

Expected Value of Production $=E P I \times C O L$ (for bonus period $)$

$$
\begin{aligned}
& =2.0 \times \mathrm{R} \$ 400,000 \\
& =\mathrm{R} \$ 800,000
\end{aligned}
$$

Savings or Loss $=E V P-A V P$

$$
\begin{aligned}
& =\mathrm{R} \$ 800,000-600,000 \\
& =\mathrm{R} \$ 200,000
\end{aligned}
$$

Labor's share $=L C V A \times$ Savings

$$
\begin{aligned}
& =0.5 \times \mathrm{R} \$ 200,000 \\
& =\mathrm{R} \$ 100,000
\end{aligned}
$$

\footnotetext{
* Source: Bergmann, Scarpello, and Hills, Compensation Decision Making, Third Edition, The Dryden Press, New York, 1998, p. 434.
}

\subsection{Improshare}

This plan was developed by Mitchell Fein em 1973 and can be branded as "improved productivity through sharing" (Bergmann, Scarpello, and Hills, 1998). The difference between this and the Scanlon and Rucker plans is that it measures the productivity of work performed by employees and ignores special adjustments attributed to aspects beyond its control. Work standards are an average of past performance obtained by means of the use of historical data, which includes the period when exogenous forces delay production as well as periods of major efficiency. Table 3 illustrates our argument.

The plan performs all the comparisons listing the amount of hours worked in relation to standard hours. As soon as the standard hours are established they are frozen and suffer modifications if any technical improvements or technological innovations occur. Most Improshare plans are established to calculate productivity increases and pay out amounts saved on weekly bases. 
Table 3. Theoretical Example of Improshare Calculation (weekly basis).

\begin{tabular}{|c|}
\hline Total plant employment $=150$ (direct and indirect) \\
\hline Average weekly production $=500$ units (based on historical data) \\
\hline Total plant hours (output value) $=150$ employees $\times 40$ hours per week \\
\hline Average value of output $=12$ hours per unit $(6,000$ hours $/ 500$ units) \\
\hline Production per week after Improshare $=650$ units \\
\hline Current productivity value $=7,800$ hours $(650 \times 12)$ \\
\hline Productivity increase $7,800-6,000=1,800$ hours \\
\hline Sharing (50\% employee $/ 50 \%$ firm $)=1,800 / 2$ hours saved for employers \\
\hline New labor costs $6,000 \times 900^{*} / 650=10.62$ hours per unit \\
\hline Premium: $900 / 6,000=15 \%$ \\
\hline Basic productivity factor $=7,800 / 6,000=1.30$ \\
\hline 900 hours are paid to employees and must be added
\end{tabular}

* Source: Bergmann, Scarpello, and Hills, Compensation Decision Making, Third Edition, The Dryden Press, New York, 1998, p. 435, adapted from Mitchell Fein, An Alternative to Traditional Managing, In., 1981, p. 43.

\section{Variable remuneration programs in Brazil}

In Brazil, the participation of workers in the profit or income of firms has been a constitutional matter since 1946, maintained by the constitutional amendment of 1969 and again by the Federal Constitution of 1988 in conformity with chapter II of the Social Rights (Martins, 1998):

Art. 7 The rights of urban and rural workers, besides others that aim to improve their social condition, are as follows:

XI $A$ share in the profits or income, not linked with remuneration and, exceptionally, participation in the firm management as defined by law.

However, this topic only assumed the power of a law in the country after the publication of Provisional Measure 794 of December 29, 1994 (hereinafter simply PM) by which means the government regulated the sharing of profit and income by workers. This PM (with the same legal power) was constantly reedited until Congress passed a vote to transform it definitely into a law.

The principal points of this PM are as follows:

(i) every firm should establish a form of profit or income sharing with its employees;

(ii) the criteria may be productivity, quality or profitability indexes;

(iii) the agreement should contemplate clear rules on participation, such as measurement mechanisms, distribution periodicity and validity period;

(iv) the payment of values as a share of profits shall observe the minimum periodicity of six months; 
(v) the negotiation instrument should be filed at the labor union;

(vi) sharing payments are exempt from labor or social security charges;

(vii) the shares attributed to employees may be deducted as operating expenses by legal entities;

(viii) income tax payable by employees shall be paid by the firm;

(ix) sharing shall not substitute or supplement the remuneration payable to any employee;

(x) the Principle of Habitualness is not applicable.

Despite the existence of criticism related to the regulation of workers sharing in the profit or income of firms by a provisional measure, both due to the mandatory nature of setting up a program of this type and due to specific aspects of the regulation, it is a widely known fact that the PM led to a considerable increase in the interest manifested by Brazilian employers and employees in this topic, generating debates on the matter and promoting the appearance of new variable remuneration programs.

According to the consulting firm Coopers \& Lybrand (1996), there are two major groups of firms in the country. One of these contemplates the more innovative firms that had established or were intending to adopt variable remuneration programs as part of their management modernization process in search of improved organizational performance before the PM was published, while the other group is said to consist of firms that deployed a profit or income-sharing system with the exclusive purpose of complying with legislation, substituting bonuses or premiums already distributed at the year-end by profit or income sharing plans to take advantage of the tax benefits, for example. Thus, the most common variable remuneration programs in the country are based on traditional methods of performance assessment and/or on accounting profit to define the amounts to be paid as a share of the profit or income (Profit-share programs).

\section{Economic value added as a management instrument on variable remuneration}

According to Stewart (1999), EVA is the operating profit minus the cost of all the capital utilized to produce this profit. Thus it can be affected positively by means of an increase in the operating profit without the need to increase the capital employed or with the use of new eapital that can be invested in projects that yield rates higher than the total capital cost. However, it can be affected negatively if managers accept projects that yield less than the total cost of capital or fail to accept projects that yield more than the cost of capital.

Ehrbar (1999) defines EVA as the "operating profit after the payment of taxes less charges on capital, appropriate both for indebtedness and for capital stock" and presents the following formula for EVA calculation.

$$
E V A=N O P A T-C \times T C,
$$


where NOPAT is the net operating profit after income tax but prior to the reduction of capital charges; $C$ is the capital percentage cost; and $T C$ is the total capital. As the total capital cost to be employed in the $E V A$ calculation corresponds to the WACC (Weighted Average Cost of Capital), the EVA formula can be rewritten as follows:

$$
E V A=N O P A T-W A C C \times T C .
$$

Both NOPAT and TC to be used to calculate EVA should undergo some adjustments in relation to accounting principles as they must be as close as possible to their economic, and not to their carrying value. Thus, for example, expenses considered for accounting purposes but that do not represent a cash outflow should be added back to NOPAT, with the exception of depreciation that does not represent a cash outflow but is a real economic expense. The main adjustments to the made to NOPAT and capital compared to the basis on the accounting data to place them in an economic basis are: R\&D; strategic investments; recording of acquisitions; entry of expenses; depreciation; restructuring charges; and taxes and adjustments to the balance sheet (Stewart, 1991; Ehrbar, 1999).

The need to transform book profit into economic profit for EVA calculations can be explained by means of the comparison between accounting and economic profit adopted by Sharpe (1981), which considers that as the accounting profit is usually different from the economic profit, the correlation between the accounting profit and value of a firm will not be perfect, in other words, accounting profit is an important source of information on value but not a perfect source or the only relevant source.

EVA can be represented by the formula shown below based on the formulas previously mentioned and considering their adaptations to the standards utilized in Brazilian literature:

$$
E V A=O P(1-\tau)-W A C C \times N O A(1-\tau),
$$

where:

$O P=$ operating profit (earnings);

$\tau=$ income tax rate;

$W A C C=$ weighted average cost of the gross capital;

NOA = net operating assets (representing the total capital applied discounting the non-interest-bearing current liabilities, which are accounts such as accounts payable and accrued expenses, that arise as spontaneous sources of financing (see, for instance, Stewart, 1991).

The weighted average cost of capital can be written as:

$$
W A C C=k_{e}\left(\frac{E}{D+E}\right)+k_{d}\left(\frac{D}{D+E}\right) .
$$


The cost of equity, $k_{e}$, represents the rate of return required by equity investors in the firm; the cost of debt, $k_{d}$, measures the cost of borrowing; $E$ and $D$ stand for equity and debt, respectively.

If we define now: $C C P=k_{e} E$ and $C C T=k_{d} D$, we get a way of making the formula for $E V A$ as simple as possible considering a taxation over the equity capital:

$$
E V A=O P(1-\tau)-C C P(1-\tau)-C C T(1-\tau) .
$$

To develop the argument more adequately we need to emphasize a feature of $E V A$, i.e., its association with the demonstration of added value and productivity (De Lucca, 1998; Gray and Mauders, 1986; Gray and Meek, 1988). For this purpose, we will have to return to the most well-known $E V A$ formula and the Value Added concept, a fundamental variable for the modern economic theory will be the starting point of our argument.

Value Added, $V A$, is reputed as being the difference between the gross value of production, $G V P$, i.e., billings, and the intermediate consumption (IC), mainly disbursed on raw material (Dornbusch and Fischer, 1994, Simonsen and Cysne, 1998). Hence,

$$
G V P-I C=V A .
$$

This amount is primarily appropriated to the employees, while the remaining portion is the gross operating profit. It is entitled gross since it has to meet other requirements until it can prove it is capable of creating value. If we denote labor costs by $L C$, then

$$
V A-L C=O P .
$$

The second appropriation is performed by the government which requests a portion of the gross operating profit, represented by the tax rate.

$$
(V A-L C)(1-\tau)=O P(1-\tau) .
$$

By substituting the operating profits in the EVA definition we obtain the following equation:

$$
E V A=O P(1-\tau)-C C T(1-\tau)-C C P(1-\tau),
$$

equivalently

$$
E V A=V A(1-\tau)-L C(1-\tau)-C C T(1-\tau)-C C P(1-\tau) .
$$

After substituting the value added by its definition we obtain the following relations:

$$
\begin{gathered}
(V A-L C)(1-\tau)=O P(1-\tau), \\
(G P V-I C-L C)(1-\tau)=O P(1-\tau),
\end{gathered}
$$

and

$$
E V A=(G P V-I C-L C)(1-\tau)-C C T(1-\tau)-C C P(1-\tau) .
$$


By substituting the gross production value by its definition, i.e., the multiplication of the price $P$ produced by the quantity sold $Q$ we arrive at:

$$
E V A=(P \times Q-I C-L C)-\tau V A+\tau L C-C C T(1-\tau)-C C P(1-\tau)
$$

If we multiply and divide the amounts produced by the amount of hours of work needed to produce them $H W$, we find:

$E V A=P\left(\frac{Q}{H W}\right) H W-I C-L C-\tau V A+\tau L C-C C T(1-\tau)-C C P(1-\tau)$ equivalently

$E V A=P \times P R O D \times H W-I C-L C(1-\tau)-\tau V A-C C T(1-\tau)-C C P(1-\tau)$.

An alternative formula although with a more limited scope can be developed by using the concept of physical productivity, $P R O D$, i.e., the number of employees used to produce a certain product. The problem with this concept is that it is necessary to specify the produced amount on an individual product basis, which results in the calculation of individualized economic values added. A simpler alternative could be to compute an amount of working hours, assuming an average number of working hours per employee and multiplying this figure by the total number of employees. In this sense, the mistake committed by working with physical productivity disappears, as the effectiveness of the operating assets is also calculated based on the number of employees since,

$$
\begin{aligned}
\left(\frac{Q}{H W}\right)\left(\frac{H W}{N O A}\right) & =\left(\frac{Q}{N W \times H P W}\right)\left(\frac{N W \times H P W}{N O A}\right) \\
& =\left(\frac{Q}{N W}\right)\left(\frac{N W}{N O A}\right)
\end{aligned}
$$

where $N W=$ is the number of workers, and $H P W=$ hours per worker. If we divide the above expression by the net operating assets $N O A$, i.e., the assets used to produce the economic value added, the result will be:

$$
\frac{E V A}{N O A}=P \times P R O D\left(\frac{H W}{N O A}\right)-\frac{I C}{N O A}-\frac{L C(1-\tau)}{N O A}-\frac{\tau V A}{N O A}-W A C C(1-\tau) \text {. }
$$

The ratios in the above expression may be defined as:

$Q / H W=$ work productivity;

$H W / N O A=$ effectiveness of the net operating assets;

$I C / N O A=$ participation of the intermediate consumption of the net operating assets;

$L C(1-\tau) / N O A=$ participation of workforce in the net operating assets; $(\tau V A) / N O A=$ participation of taxation over the value added in the net operating assets; 
Equation (1) shows us all the variables that increase the economic earning, i.e.:

a) price increase;

b) productivity increase;

c) increase in the efficiency of the net operating assets;

d) reduction in the participation of the intermediate consumption of net operating assets;

e) reduction to the payroll as a proportion of the net operating assets;

f) reduction to the tax charged on value added as a proportion of the net operating assets;

g) reduction to the weighted average cost of the net equity (capital employed);

We would like to emphasize that, despite the fact that price and productivity act in a positive manner on the increase of the economic value added, the multiplication of both items can result in a smaller amount since the relationship between them is inverse. Our next task is to analyze gainsharing plans in light of equation (2).

\section{The influence of the Scanlon, Rucker and improshare plans on economic value added}

The plans we have covered possess two characteristics that we intend to highlight. Firstly, because they valorize group work. The second characteristic is that they are focused on the creation of value for the firm, despite the fact that a significant relation does not always exists between value creation measures for the firm (represented by economic value added) and the creation of value for stockholders, represented by an increase in the price of shares (see, Peterson and Peterson, 2000).

The Scanlon Plan privileges the growth of gross production value ( $G P V)$ in relation to the payroll $(T C)$. The equation of the expanded EVA formula shows that this leads to an increase in the creation of value:

$$
E V A=(G P V-I C)-\tau V A-T C(1-\tau)-C C T(1-\tau)-C C P \times(1-\tau) .
$$

The Rucker Plan uses the Economic Productivity Index, EPI, which is inverse to the $T C / V A$ ratio.

$$
E P I=\frac{V A}{T C}
$$

which implies

$$
V A=E P I \times T C .
$$

The expanded $E V A$ formula can be expressed in terms of the EPI as:

$$
E V A=E P I \times T C(1-\tau)-T C(1-\tau)-C C T(1-\tau)-C C P(1-\tau) .
$$

This shows that if an amount is stipulated for the payroll, the increase in the economic productivity index, EPI, stimulates the creation of value. 
The last plan to be examined is Improshare. To relate this plan with value creation we need to refer to the third version of the expanded $E V A$ formula, equation (2), where productivity appears in the formula in an explicit fashion. Productivity in this work is expressed in product units per hour of work $(Q / H W)$ whereby Improshare utilizes hours of work per product, the opposite of our relation. Productivity gains are expressed by a reduction in the amount hours per unit produced or by an increase in the unit of product per hour of work, which increase the creation of value.

We should emphasize that the methods utilized for the increase economic added value are not equivalent as we might see a payroll reduction and an increase in the gross production value originating from a price increase or increase in the efficiency of the employed capital. In all cases a greater value creation measured by an EVA increase should be associated with a bonus program linked to a bonus bank (Stewart, 1991) to avoid distortions caused by short-term performance increases (group), which are not associated with structural changes.

\section{Conclusions}

The purpose of this work was to analyze variable remuneration programs in the light of a principle that we consider fundamental: remuneration should be related to the creation of value by the firm. In this sense we have allowed ourselves to make a bold affirmation: measures that do not take the own capital cost into account are not very suitable to measure the creation of value and should be discarded. Thus, we still believe that economic value added is a highly efficient indicator of performance as regards value creation.

The variable remuneration programs examined herein were more privileged than others as they presented characteristics we consider essential in the case of Brazil. If we were asked to recommend the best option between cash remuneration or compensation in firm shares, our answer would be that the ideal is a combination of both. More precisely we defend the idea of a variable remuneration program based on three components. The first consists of a cash remuneration. The variable cash remuneration must be linked to a productivity increase. But which remuneration plans privilege productivity? The answer to this question is gainsharing plans, specifically those covered in this paper. The prioritization of these plans is even as they contribute towards value creation. In this manner, we have managed to associate variable remuneration with the variance of value smoothed out by the juridical apparatus of the Brazilian legislation dealing with the topic, which also prioritizes productivity gains. Thus, part of the remuneration should be in money and contemplate a plan that prioritizes increased productivity.

Among the programs discussed in this work, the compensation program related to results based on EVA is not yet part of our reality as there are few firms in the country that adopt management models based on EVA. Our recommendation is that they start utilizing EVA. The second component of the program corresponds to the establishment of a stock plan for employees (employee stock ownership plan, ESOP) due to the tax incentives granted by US 
legislation for these plans that could be incorporated to Brazilian legislation (Amato, 2000). Long-term incentive programs such as ESOPs would require specific legislation on the theme, besides tax incentives for implementation. No major movement in this direction has been observed in the country. However, considering the demands imposed by the tax authorities, it would be prudent to rapidly implement them with the objective of improving the competitive performance of firms that operate in Brazil. The third component is the deployment of a stock option program, but which an essential characteristic not observed in option plans. For an employee to exercise the option, he or she would have to create value for the firm, which can be translated as a positive variance in the economic value added. The positive variance should award employees who help to reduce negative economic value added.

Stock purchase option programs are the most popular programs in Brazilian firms that apparently limit them to executives from the highest organizational levels. Therefore, they have practically no connection with the creation of value for all the stakeholders. We emphasize the word stakeholders, since we have shown that the increase in economic value added promoted by a productivity gain can benefit stockholders, executives and employees from medium and low hierarchical levels, provided the latter are rewarded for a greater creation of value and not only the executives.

Furthermore, we should emphasize that the financial focus presents limitations that should be overcome by assessing all the political and social factors that motivate employees. Having reached the end of these conclusions, we suggest that the concepts dealt with in this paper be selected as the subject of empirical surveys to fully verify the levels of value creation reached through the use of variable remuneration.

\section{References}

Ehrbar, A. (1999). Valor Econômico Agregado: A Verdadeira Chave para a Criação da Riqueza. Rio de Janeiro: Qualitymark.

Amato, F. A. (2000). Employee Stock Ownership. ACA News, Scottsdale. February.

Bergmann, T. J., V. G. Scarpello, and F. S. Hills. (1998). Compensation Decision Making, New York: The Dryden Press.

Coopers \& Lybrand. (1996). Remuneração Estratégica: A Nova Vantagem Competitiva (Strategic Remuneration: The New Competitive Advantage). São Paulo: Atlas.

De Lucca, M., and M. Martins. (1998). Demonstração do Valor Adicionado - do Cálculo, da Riqueza criada pela empresa ao valor do PIB (Demonstration of Value Added - from the Calculation and Wealth Created by the company through to the GIP value). São Paulo: Atlas.

Dornbush, R, and S. Fisher. (1994). Macroeconomics, McGraw Hill. 6th ed.

Gray, S, and G. Meek. (1988). The Value Added Statement: An Innovation for US Companies? Accounting Horizons, 2(2), June.

Gray, S., and K. Mauders. (1980). Value Added Reporting: Uses and Measurement, London: The Association of Certified Accountants.

Martins, S. P. (1998). Direito do Trabalho (Labor Law). São Paulo: Atlas.

Peterson, P. P., and D. R. Peterson. (1996). Performance of Companies and Value Added Measures. The Research Foundation of the Institute of Chartered Financial Analysts, Charlottesville. Published in Brazil by ABAMEC. 
Prahalad, C. K. (1999). Reexame de Competências (Re-examination of Competencies), HSM Management. Nov/Dec.

Sharpe, W. F. (1981). Investments, New Jersey: Prentice-Hall.

Simonsen, M. H., and R. P. Cysne. (1995). Macroeconomia, São Paulo: Atlas.

Stewart, G. B. (1991). The Quest for Value: The EVA Management Guide, Harper Collins. 